НАУКОВИЙ ВІСНИК

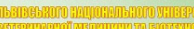

Cientific messegger of Livi National University
Veterinary Meedicine and Biotechnologies

now

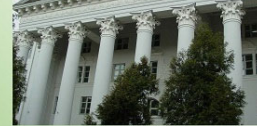

Toм 21 № 91

2019
Науковий вісник Дьвівського національного університету ветеринарної медицини та біотехнодогій імені С.3. Гжицького. Серія: Сідьськогосподарські науки

Scientific Messenger of Lviv National University of Veterinary Medicine and Biotechnologies. Series: Agricultural sciences

UDC 619:612.396

\title{
Hydrocarbon metabolism in mice during preclinical studies of modified starch
}

\author{
A.H. Vovkohon \\ Bila Tserkva National Agrarian University, Bila Tserkva, Ukraine
}

Article info

Received 04.09.2019

Received in revised form 07.10 .2019

Accepted 08.10.2019

Bila Tserkva National Agrarian University, pl. Soborna, $8 / 1$, Bila Tserkva, 09117, Ukraine. Tel.: +38-067-458-21-35 E-mail: alinavovk1@ukr.net

Vovkohon, A.H. (2019). Hydrocarbon metabolism in mice during preclinical studies of modified starch. Scientific Messenger of Lviv National University of Veterinary Medicine and Biotechnologies. Series: Agricultural sciences, 21(91), 33-36. doi: 10.32718/nvlvet-a9106

Preclinicl studies of new nutritional supplements include the establishment of not only harmlessness, lethal or semi-lethal dose, but also biochemical signs of the laboratory animals at certain doses of the substance. New food additives include modified starch. Of scientific interest are the studies of white mice hydrocarbon metabolism considering the safety of modified starch. The study of modified starch safety was performed according to the established requirements. Eighteen 2-month-old laboratory mice (females) were used for the study, with an average body weight of 19-21 g. Groups were formed using the randomization method. Each group consisted of six experimental animals. Experiments on the harmlessness of modified starch on white mice were performed according to the scheme, where animals from the control group were intramuscularly administered $0.3 \mathrm{~cm}^{3}$ of $0.9 \% \mathrm{NaCI}$ solution. Mice from the first experimental group were led with a $5.0 \%$ solution of modified starch. Animals from experimental II were guided by a 10.0\% solution of modified starch. The volume of solutions of modified starch was $0.3 \mathrm{~cm}^{3}$. Blood serum of laboratory mice was tested for glucose, lactic and pyruvic acid levels, and the liver was used to determine glycogen level. All those actions were performed according to current bioethics requirements. It was experimentally proven that on the eleventh day from the beginning of injecting the $0.3 \mathrm{~cm}^{3} 5.0 \%$ and $10.0 \%$ solution of modified starch in the blood serum of the laboratory mice glucose content did not differ from those obtained in control animals, which were injected with saline. When using the test solutions, itt was found that the levels of lactic and pyruvic acid in the serum of experimental animals were within the physiological standards. In those mice that were injected intragastrically the increased doses of modified starch the level of glycogen in the liver was about $39.7-40.1 \mathrm{~g} / \mathrm{kg}$ which corresponded to physiological standards. Thus, a single injection of $0.3 \mathrm{~cm}^{3} 5.0 \%$ and $10.0 \%$ solution of modified starch does not cause disorder of hydrocarbon metabolism in mice. acid.

Key words: liver, serum, modified starch, laboratory animals, glycogen, glucose, lactic acid, pyruvic

\section{Вуглеводневий обмін у мишей за доклінічних досліджень модифікованого крохмалю}

\author{
А.Г. Вовкогон
}

Білочерківський національний аграрний університет, м. Біла Церква, Украӥна

Доклінічні дослідження нових харчових добавок передбачають встановлення не лише нешкідливсті, летальної чи напівлетальної дози, а й біохімічних показників у організмі лабораторних тварин за визначених доз речовини. До нових харчових добавок належить модифікований крохмаль. Науковий інтерес становлять дослідження вуглеводневого обміну в організмі білих митей за встановлення нешкідливості модифікованого крохмалю. Дослідження нешкідливості модифікованого крохмалю проводили згідно зі встановленими вимогами. Для дослідження було використано 18 лабораторних мишей двомісячного віку (самки), які мали середню масу тіла 19-21 г. Групи формували, застосовуючи метод випадковості. Кожна група налічувала по шість піддослідних тварин. Експерименти із нешкідливості модифікованого крохмалю на білих митах проводили за схемою, де тваринам із контрольної групи внутрішньошлунково водили по 0,3 $\mathrm{cm}^{3}$ 0,9\% розчину NaCI. Мишам із I дослідної групи водили 5,0\% розчин модифікованого крохмалю. Тварини із ІІ дослідної водили 10,0\% розчин модифікованого крохмалю. Об'єм розчинів модифікованого крохмалю становив по 
0,3 см³. В сироватиі крові лабораторних митей вивчали вміст глюкози, молочної та піровиноградної кислоти, у печінці встановлювали вміст глікогену. Всі маніпуляції із мимами виконувались згідно з сучасними вимогами біоетики. Експериментально доведено, изо на одинадияту добу від початку ведення лабораторним митам по 0,3 см 5,0\% та 10,0\% розчину модифікованого крохмалю у сироватці крові ичих тварин вміст глюкози не відрізнявся від показників, одержаних у контрольних тварин, яким водили фізіологічний розчин. Виявлено, за використання досліджуваних розчинів вміст молочної та піровиноградної кислоти у сироватці крові дослідних тварин був у межах фізіологічної норми. Вміст глікогену в печіниі мишей, яким внутрішньошлунково водили підвищені дози модифікованого крохмалю, був на рівні 39,7-40,1 г/кг, шуо відповідало фізіологічним нормам. Таким чином, одноразове ведення 0,3 $\mathrm{cm}^{3}$ 5,0\% та 10,0\% розчину модифікованого крохмалю не викликає порушень вуглеводневого обміну в організмі мишей.

Ключові слова: печінка, сироватка крові, модифікований крохмаль, лабораторні тварини, глікоген, глюкоза, молочна кислота, піровиноградна кислота.

\section{Вступ}

Використання видозмінених, модифікованих та нових харчових добавок потребує ретельних токсикологічних досліджень. В лабораторних умовах Інституту харчових технологій Білоцерківського національного аграрного університету одержано модифікованих крохмаль як носій для стабілізації заквасок для виготовлення кисломолочних напоїв.

Із модифікованим крохмалем проведено ряд доклінічних досліджень, в тому числі встановлена його нешкідливість на білих мишах. Науковий інтерес становить вивчення ряду показників вуглеводневого обміну в організмі лабораторних тварин за проведення токсикологічних досліджень нових харчових добавок (Nafikov \& Beitz, 2007). Ці дані слугуватимуть фундаментальною основою для майбутніх токсикологів, біологів та біотехнологів під час вивчення доклінічних властивостей видозмінених (модифіковаих) форм крохмалю.

Аналізуючи процес вуглеводневого обміну в організмі тварин, проводять визначення вмісту в тканинах і органах маркерних показників: вміст глюкози, молочної кислоти та піровиноградної кислоти в сироватці крові та вміст глікогену в печінці (Nafikov \& Beitz, 2007).

Глюкоза $є$ енергетичним джерелом живленням для вищих організмів. Життєвою необхідністю є забезпечення вмісту глюкози в крові у фізіологічній нормі (Aschenbach et al., 2010). Більша частина глюкози генерується глюконеогенезом з використанням летких глюкогенних попередників (De Koster \& Opsomer, 2013). У нормі вміст глюкози в крові мишей становить 4,2-6,4 ммоль/л (Gorjacheva \& Makarova, 2016).

Піровиноградна кислота відіграє проміжну роль у метаболізмі жирів, білків та вуглеводів. Сполука за гіпотезою Эмбдена-Мейерхофа $є$ попередником молочної кислоти у м'язевому гліколізі. У різних тканинах в анаеробних умовах піровиноградна кислота перетворюється в молочну. Пірувати (різні солі піровиноградної кислоти) є кінцевим метаболітом в процесі гліколізу. Одна молекула глюкози перетворюється на дві молекули піровиноградної кислоти. За наявності Оксигену піровиноградна кислота перетворюється в ацетил-кофермент A (Cody et al., 2000).

Молочна кислота є продуктом анаеробного перетворення. Показник вмісту молочної кислоти в крові служить індикатором гіпоксії тканин для ідентифікації важкості захворювання (Sharkey \& Wellman, 2015; Di Mauro \& Schoeffler, 2016). У тварин L-молочна кислота постійно синтезується із пірувату за участі ензиму лактатдегідрогенази за фізіологічного обміну речовин та фізичного навантаження. За підвищених фізичних вправ вміст молочної кислоти в крові може підвищуватись (Goodwin et al., 2007). Молочна кислота є головним антагоністом для рецептора органічної кислоти як гідроксикарбонова (Offermanns et al., 2011; Offermanns et al., 2018).

У клінічно здорових мишей вміст молочної кислоти в сироватці крові становить 0,6-2,0 ммоль/л (Goodwin et al., 2007; Katunina et al., 2015).

У тваринному організмі у м'язовій тканині вміст глікогену становить 1-2\%, в печінці до 5\%. Цей вуглевод виконує функцію джерела енергії під час достатньої годівлі, а також під час голодування. Анаболізм і катаболізм глікогену в печінці тварин контролюється дією ряду ензимів: глікогенфосфорилазою та глікогенсинтетазою (Roach et al., 2012). Вміст глікогену в печінці залежить від вмісту глюкози у крові (Garverick et al., 2013). За умов голодування глікоген, який міститься в печінці, мобілізується для поновлення глюкози в крові (Izumida et al., 2013).

Метою роботи є дослідження ряду показників вуглеводневого обміну в організмі мишей за умов встановлення на них нешкідливості модифікованого крохмалю.

\section{Матеріал і методи досліджень}

Для дослідження було використано 18 лабораторних мишей двомісячного віку (самки), які мали середню масу тіла 19-21 г. Групи формували, застосовуючи метод випадковості. Кожна група налічувала по шість піддослідних тварин (табл. 1).

Експерименти із нешкідливості модифікованого крохмалю на білих мишах проводили за схемою, де тваринам із контрольної групи внутрішньошлунково водили по $0,3 \mathrm{~cm}^{3} 0,9 \%$ розчину $\mathrm{NaCI}$. Мишам iз I дослідної групи водили 5,0\% розчин модифікованого крохмалю. Тварини із II дослідної водили $10,0 \%$ розчин модифікованого крохмалю. Об'єм розчинів модифікованого крохмалю становив по $0,3 \mathrm{~cm}^{3}$. 
Таблиця 1

Схема виконання дослідження нешкідливості модифікованого крохмалю на мишах

\begin{tabular}{ccl}
\hline Група & $\begin{array}{c}\text { Чисельність мишей у } \\
\text { групі, гол. }\end{array}$ & \multicolumn{1}{c}{ Дози розчинів, які досліджуються } \\
\hline Контрольна & 6 & По $0,3 \mathrm{~cm}^{3} 0,9 \%$ розчину NaCІ на одну голову \\
І дослідна & 6 & По $0,3 \mathrm{~cm}^{3} 5,0 \%$ розчину модифікованого крохмалю на одну голову \\
II дослідна & 6 & По $0,3 \mathrm{~cm}^{3} 10,0 \%$ розчину модифікованого крохмалю на одну голову \\
\hline
\end{tabular}

Поводження із піддослідними тваринами проводилось із додержанням “Загальних етичних принципів експериментів на тваринах", прийнятих Першим Національним конгресом 3 біоетики (Київ, 2001). По завершенні експерименту тривалістю десять діб після наркозу мишей забивали, відбирали проби крові та внутрішні органи 3 метою виконання ряду біохімічних досліджень. Вміст молочної кислоти у сироватці крові тварин досліджували за Баркером та Саммерсоном (Chechetkin et al., 1980), вміст піровиноградної кислоти у сироватці крові вивчали за методикою, описаною у (Chechetkin et al., 1980). Визначення вмісту глікогену у печінці мишей проводили за методикою описаною у (Kushnir, 2010). Вміст глюкози визначали у сироватці крові $з$ проведенням кольорових реакцій, використовуючи орто-толуїдиновий реактив відповідні методики (Instrukcija do naboru reaktyviv..., 2003).

Одержані дані піддавали біометричній обробці. Встановлювали показники середніх арифметичних величин (М) та відхилення до середнього значення (m). Виконували розрахунки щодо вірогідності між одержаними даними (Р). Вірогідність вирахуваної різниці між середніми значеннями даним розрахову- вали, застосовуючи критерії Стьюдента (t) (Plohinskij, 1969).

\section{Результати та їх обговорення}

Перед взяттям проб крові, тканин та органів проводили етологічні дослідження із лабораторними мишами, яким водили розчин модифікованого крохмалю. Десятидобове спостереження за тваринами показало, що різні дози модифікованого крохмалю не спричинили загибелі мишей. Клінічний стан тварин до кінця експерименту був задовільним.

Встановлено, що у крові мишей, яким не водили модифікованого крохмалю (контроль), вміст глюкози був на рівні 4,1 ммоль/л. Введення мишам $0,3 \mathrm{~cm}^{3}$ 5,0\% розчину модифікованого крохмалю (I дослідна група) не викликало вірогідного підвищення вмісту глюкози в сироватці крові тварин. Різниця із контролем становила 2,4\%. Зниження вмісту глюкози у сироватці крові лабораторних мишей, яким водили по $0,3 \mathrm{~cm}^{3} 10,0 \%$ розчину модифікованого крохмалю, на $4,8 \%$ було в межах похибки. Вміст глюкози у тварин iз контрольної та дослідної групи був у межах фiзioлогічної норми (табл. 2).

\section{Таблиця 2}

Біохімічні показники в сироватці крові мишей за дії модифікованого крохмалю $\mathrm{M} \pm \mathrm{m}, \mathrm{n}=6$

\begin{tabular}{lccc}
\hline \multirow{2}{*}{ Група } & \multicolumn{3}{c}{ Вміст речовини } \\
\cline { 2 - 4 } & глюкоза, ммоль/л & молочна кислота, ммоль/л & піровиноградна кислота, ммоль/л \\
\hline Контрольна & $4,1 \pm 0,28$ & $1,41 \pm 0,134$ & $0,076 \pm 0,0086$ \\
I дослідна & $4,2 \pm 0,33$ & $1,29 \pm 0,231$ & $0,083 \pm 0,0054$ \\
II дослідна & $3,9 \pm 0,18$ & $1,52 \pm 0,143$ & $0,090 \pm 0,0079$ \\
\hline
\end{tabular}

У сироватці крові лабораторних тварин із контрольної групи вміст молочної кислоти становив 1,41 ммоль/л. Ведення мишам 5,0\% розчину модифікованого крохмалю не супроводжувалось вірогідним зниженням молочної кислоти в сироватці крові. Вміст молочної кислоти у сироватці крові мишей, яким водили по $0,3 \mathrm{~cm}^{3} 10,0 \%$ розчину модифікованого пектину був у межах фізіологічної норми і суттєво не відрізнявся від показників контролю.

Дослідження вмісту піровиноградної кислоти в сироватці крові показало, що у мишей із контрольної групи цей показник був на рівні 0,076 ммоль/л. Введення лабораторним тваринам із I дослідної групи розчину модифікованого крохмалю призвело до зростання вмісту піровиноградної кислоти у сироватці крові. Різниця була в межах похибки. Не мало вірогідного характеру зростання вмісту піровиноградної кислоиу мишей, яким водили $10,0 \%$ розчин модифікованого крохмалю.
Таким чином, введення лабораторним тваринам підвищених доз модифікованого крохмалю негативно не впливало на показники вуглеводневого обміну у сироватці крові.

За вмістом глікогену в печінці можливо судити про анаболічні та катаболічні процеси вуглеводневого обміну в організмі тварини. У лабораторних мишей, яким водили лише фізіологічний розчин, вміст глікогену в печінці відповідав фізіологічним нормам і становив 42,3 г/кг. У печінці тварин із І дослідної групи вміст глікогену був меншим, ніж у контролі, на 6,1\%. Проте різниця не мала вірогідного характеру (табл. 3).

За використання $0,3 \mathrm{~cm}^{3} 10,0 \%$ розчину модифікованого крохмалю не виявляли вірогідного зменшення вмісту глікогену в печінці лабораторних тварин на кінець експерименту. 
Таблиця 3

Результат біохімічного дослідження у печінці мишей, $\mathrm{M} \pm \mathrm{m}, \mathrm{n}=6$

\begin{tabular}{lc}
\hline \multicolumn{1}{c}{ Група } & Вміст глікогену, г/кг \\
\hline Контрольна & $42,3 \pm 3,76$ \\
I дослідна & $39,7 \pm 2,78$ \\
II дослідна & $40,1 \pm 3,56$ \\
\hline
\end{tabular}

Збільшення у розчині масової частки модифікованого крохмалю до 10,0\% не викликало суттєвого зниження вмісту глікогену в печінці мишей II дослідної групи. Різниця із даними контрольної групи була на рівні 5,2\%. Отже, за разового ведення лабораторним мишам розчинів модифікованого крохмалю у їх організмі не констатується порушення вуглеводневого обміну.

\section{Висновки}

1. Разове внутрішньошлункове введення $0,3 \mathrm{~cm}^{3}$ 5,0\% розчину модифікованого крохмалю не викликає вірогідного зниження або підвищення вмісту глюкози, молочної кислоти, піровиноградної кислоти у сироватці крові та вмісту глікогену в печінці лабораторних мишей.

2. За внутрішньошлункового введення тваринам $0,3 \mathrm{~cm}^{3} 10,0 \%$ розчину модифікованого крохмалю показники вуглеводневого обміну в їхньому організмі перебувають у межах фізіологічної норми.

Перспективним напрямом дослідження є встановлення біотехнологічних параметрів іммобілізації клітин мікроорганізмів на модифікованому крохмалі.

\section{References}

Nafikov, R., \& Beitz, D. (2007). Carbohydrate and Lipid Metabolism in Farm Animals. Journal of Nutrition, 137(3), 702-705. doi: 10.1093/jn/137.3.702.

Aschenbach, J.R., Kristensen, N.B., Donkin, S.S., Hammon, H.M., \& Penner, G.B. (2010). Gluconeogenesis in dairy cows: The secret of making sweet milk from sour dough. IUBMB Life, 62(12), 869-877. doi: 10.1002/iub.400.

De Koster, J.D., \& Opsomer, G. (2013). Insulin resistance in dairy Cows. Vet Clin North Am Food Anim Pract., 29(2), 299-322. doi: 10.1016/j.cvfa.2013.04.002.

Gorjacheva, M.A., \& Makarova, M.N. (2016). Osobennosti provedenija gljukozotolerantnogo testa u melkih laboratornyh gryzunov (myshi i krysy). Mezhdunarodnyj vestnik veterinarii, 3, 155-160. https://elibrary.ru/item.asp?id=26740182 (in Russian).

Cody, G.D., Boctor, N.Z., Filley, T.R. et al. (2000). Primordial Carbonylated Iron-Sulfur Compounds and the Synthesis of Pyruvate. Science New Series, 289, 1337-1340. doi: 10.1126/science.289.5483.1337.

Sharkey, L.C., \& Wellman, M.L. (2015). Use of Lactate in Small Animal Clinical Practice. Clin Lab Med., 35(3), 567-577. doi: 10.1016/j.cll.2015.05.006.
Di Mauro, F.M., \& Schoeffler, G.L. (2016). Point of Care Measurement of Lactate. Top Companion Anim Med., 31(1), 35-43. doi: 10.1053/j.tcam.2016.05.004.

Goodwin, M.L., Harris, J.E., Hernández, A., \& Gladden, L.B. (2007). Blood lactate measurements and analysis during exercise: a guide for clinicians. Journal of Diabetes Science and Technology, 1(4), 558-569. doi: $10.1177 / 193229680700100414$.

Katunina, N.P., Stratienko, E.N., \& Ceeva, F.N. (2015). Vlijanie novyh himicheskih soedinenij, ostroj gipoksii $\mathrm{s}$ giperkapniej $\mathrm{i}$ ih sochetannogo dejstvija na nekotorye pokazateli glikoliticheskogo puti obmena uglevodov u myshej. Vestnik Brjanskogo gosudarstvennogo universiteta, 39-40 (in Russian).

Offermanns, S., Colletti, S.L., \& Lovenberg, T.W. (2011). International Union of Basic and Clinical Pharmacology. LXXXII: Nomenclature and Classification of Hydroxy-carboxylic Acid Receptors (GPR81, GPR109A, and GPR109B). Pharmacological Reviews, 63(2), 269-290. doi:10.1124/pr.110.003301.

Offermanns, S., Colletti, S.L., \& IJzerman, A.P. (2018). Hydroxycarboxylic acid receptors. IUPHAR/BPS Guide to Pharmacology. International Union of Basic and Clinical Pharmacology, 13.

Roach, P.J., Depaoli-Roach, A.A., Hurley, T.D., \& Tagliabracci, V.S. (2012). Glycogen and its metabolism: some new developments and old themes. Biochem J., 441(3), 763-787. doi: 10.1042/BJ20111416.

Garverick, H.A., Harris, M.N., \& Vogel-Bluel, R. et al. (2013). Concentrations of nonesterified fatty acids and glucose in blood of periparturient dairy cows are indicative of pregnancy success at first insemination. J Dairy Sci., 96(1), 181-188. doi: 10.3168/jds.20125619.

Izumida, Y., Yahagi, N., Takeuchi, Y. et al. (2013). Glycogen shortage during fasting triggers liver-brain-adipose neurocircuitry to facilitate fat utilization. Nature Communications, 4, 2316. doi: 10.1038/ncomms3316.

Chechetkin, A.V., Voronjanskij, V.I., Pokusaj, G.G., Kartashov, N.I., Doktorovich, N.L., \& Kirichenko, I.V. (1980). Praktikum po biohimii sel'skohozjajstvennyh zhivotnyh. M.: Vysshaja shkola (in Russian).

Kushnir, O.Ju. (2010). Vplyv melatoninu na pokaznyky vuglevodnogo obminu $\mathrm{V}$ shhuriv $\mathrm{z}$ aloksanovym diabetom: avto- ref. dys. na zdobuttja nauk. stupenja kand. med nauk: spec. 03.00.04 "Biohimija". Instytut gerontologii' im. D.F. Chebotar'ova. K. (in Ukrainian).

Instrukcija do naboru reaktyviv dlja vyznachennja gljukozy v biologichnyh ridynah po kol'orovij reakcii' z orto-tolui'dynovym reaktyvom (kat. № NR009.01). Zatverdzhena Instytutom hirurgii' ta transplantologii' AMN Ukrai'ny vid 10 zhovtnja 2003 r. K., 2003, 2 (in Ukrainian).

Plohinskij, N.A. (1969). Rukovodstvo po biometrii dlja zootehnikov. Moskva: Kolos (in Russian). 